\title{
The First Step to Communication with Environmentally Responsible Consumer: Measuring Environmental Consciousness of Turkish Consumers ${ }^{1}$
}

\author{
Yavuz TUNA \\ Anadolu Üniversitesi-TURKEY
}

Levent ÖZKOÇAK

Anadolu Üniversitesi-TURKEY

\begin{abstract}
In recent years a growing concern for global warming and environmental issues has become apparent. Turkey as a rapidly developing country has several environmental problems. In that situation, the attitudes towards to environment and the consciousness level of the Turkish consumers have gained much more importance. For the purpose of increasing the level of consciousness about environmental issues, communication professionals have to establish a relationship between a positive environmental attitudes and environmentally responsible behaviors through the means of communication. Before designing and implementing any kind of communication process, the characteristics and current consciousness level of target group has to be clearly identified. Therefore, the aim of this study is to explore the attitudes of the Turkish consumers regarding to their current environmental consciousness and their willingness to adopt environmentally friendly consumption behavior. The environmental consciousness survey used in this study was delivered to the 186 students of 298 attending the first year obligatory courses in Communication Sciences Faculty. In this study, the environmental consciousness was formed by the factors related to awareness and act, concern about environment and willingness, were statistically were analyzed in terms of the opinions of the respondents concerning the environmental consciousness in terms of gender, the region that they came from, their department in the faculty of communication sciences, education level of parents, any kind of training concerning the environmental issues or any environmental associations or social clubs memberships.
\end{abstract}

\footnotetext{
${ }^{1}$ This paper has been presented in " International Conference on Communication and Environment: Transformation for a Sustainable Tomorrow” in Penang, Malaysia, at 9-11 December 2009,
} 


\section{Introduction}

The unconscious use of natural resources for the requirements of humanity and inconsiderate consumption habits of the people have led to irreversible environmental destructions. Instead of controlling the tools and means of production, the resources are exploited massively by humanity. As a result of that fact, humanity has very important problem is related to unfair access to these sources. Therefore in the world, $20 \%$ of humanity is consuming $80 \%$ of the natural resources. For half a century, more energy-consuming human activities aiming at satisfying the so-called "well-being" and "comfort" of humanity caused to the energy resources have diminished gradually. Obviously, it is possible to say that our planet and all its inhabitants are today threatened by a potential global ecological crisis (Miran and others, 2008).

In the few decades with the economic emergence in Turkey has brought with it fears of increased environmental degradation. As an experience of high levels of growth in Turkey's economy, the increase in industrial production resulted in higher levels of pollution and greater risks to the country's environment. Besides these, with the rise of domestic energy consumption, Turkish energy consumption has risen dramatically over the past 20 years (http://www.nuce.boun.edu.tr/turkey.html).

Several social and environmental associations and pressure groups, organizations in many parts of the world have emerged, along with government efforts, to promote the cause of the environment to make it a safe place for living for current and future generations with the increasing ecological concerns in recent years. Therefore, many governments have come under pressure to push for legislation to protect the environment. Several laws have, consequently, come out in this respect. At least partly, this has stimulated several organizations to reconsider their business policies to align themselves with the international trend of environmental commitment. (Alsmadi,2007). By the means of well designed policies related to environment, individuals get more aware for environment over time. With the renewability characteristics of the nature, a better natural balance will be formed (Doğan, 2003). The demand for recyclable commodities has been stimulated to increase in awareness and sensitivity for environmental pollution. This fact extends the usage time of resources (Yücel et al., 2003). 
In many times, people can exhibit low levels of communication about the problematic situation because they do not recognize it as a problem. (Major,1993). Therefore, an important point to protect environment and to encourage awareness before any kind of legislation concerning the environmental issues is to establish a relationship between a positive environmental attitude and environmentally responsible behavior. From the perspective of public policy standpoint, it is important to know the motivational cues and reasons for consumers to buy environmentally friendly products (Mostafa, 2007). As a result of increase in the consciousness concerning the environment and its scarce resources, consumers are searching for ecological brands and items. There is a growing amount of evidence indicates that consumers choose the products or avoid others based on their impact on the natural environment (Laroche, Bergeron, \& Barbaro-Forleo, 2001). Additionally, many surveys have shown that consumers if they believe that special brand will help the environment they are choosing that brand over the others.

The communication process based on environmental issues concerning the process of planning, producing, and disseminating, or conducting research related to, written, spoken, and/or pictorial messages about the environment, environmental issues, and/or environmental management. Therefore, environmental communicators has to seek in different situations and ways to encourage public awareness of environmental problems; underlying principles issues, and options in public understanding and a public commitment to individual and collective action (Schoenfeld and Ross, 1978). In our study the sample group consists of the students as consumers were selected from the various departments of Communication Sciences Faculty. It is obvious that the students will work on the field as communication professionals and they will use that kind of communication processes to encourage public awareness based on environmental issues.

As a communication tool, social marketing and other communication processes can be used by the communication professionals to promote social objectives like environmental consciousness. Therefore, before implementing and designing any social marketing or any communication campaigns, the awareness level concerning the knowledge, beliefs, attitudes and customs of the target group has to be determined. Therefore in the process of solution model related to environmental problems, determining the awareness is located in the first rung of the ladder. This solution model of environmental problems covers 1) eliciting the 
awareness for environment and the affecting factors, 2) providing a real sensitivity to environment by eligible education systems, 3) accessing the solved environmental problems (Miran and others, 2008)

In the light of above mentioned solution model, the aim of this study is to investigate if there is any significant differences among the opinions of the respondents concerning the environmental consciousness in terms of gender, the region that they came from, their department in the faculty of communication sciences, education level of parents, any kind of training concerning the environmental issues or any environmental associations or social clubs memberships. In this study, the environmental consciousness was formed by the factors related to awareness and act, concern about environment and willingness.

\section{Data Collection, Analysis and Results}

In this study, combination of several measures was applied. As a result, in the survey, a 5point Likert scale, with $5=$ strongly agree and $1=$ strongly disagree was used for all items. The opinions toward environmental consciousness scale contain 47 items; 30 were adapted from the items used in past environmental attitudes scale; and 17 items were included based on reviews of the environmental concern and behavior literature (Haytko \& Matulich, 2008). Additionally 8 demographic items concerning to gender, the region that they came from, their department in the faculty of communication sciences, education level of parents, any kind of training related to environmental issues or membership to any environmental associations were used to get personal information from the target group.

The survey was used in this study was delivered to the Faculty of Communication Sciences. The faculty of Communication Sciences in Anadolu University in the city of Eskisehir is located in central Anatolia has 4 departments. These departments are Cinema and Television, Communication, Public Relations and Advertising, Journalism. The environmental consciousness survey was applied to the 186 students from totally 298, attending the first year obligatory courses of four departments. In the light of above mentioned data, $64 \%$ of total population was represented in this study. The distribution of the respondents in terms of gender, the region that they came from, their department in the faculty of communication sciences, education level of parents, any kind of training related to environmental issues or membership to any environmental associations or social clubs were listed in the table 1. 


\section{Table 1}

The distribution of the respondents in terms of demographic characteristics

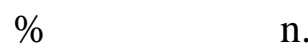

\begin{tabular}{llcc}
\hline GENDER & & & \\
\hline \hline & male & 60 & 111 \\
& female & 40 & 75 \\
\hline
\end{tabular}

THE REGION BEFORE COMING TO FACULTY

\begin{tabular}{lcc}
\hline \hline Northwest Anatolia & 36.6 & 68 \\
West Anatolia & 20.4 & 38 \\
Central Anatolia & 23 & 43 \\
Other regions & 20 & 37 \\
\hline
\end{tabular}

EDUCATION OF FATHER

\begin{tabular}{lcc}
\hline \hline Compulsory education & 42.2 & 78 \\
High school & 34 & 63 \\
University & 24 & 44 \\
\hline
\end{tabular}

EDUCATION OF MOTHER

$\begin{array}{lcc}\text { Compulsory education } & 63.2 & 117 \\ \text { High school } & 26.5 & 49 \\ \text { University } & 10.3 & 19\end{array}$

DEPARTMENT

\begin{tabular}{lcc}
\hline \hline Communication & 41.4 & 77 \\
Cinema\&Television & 9.7 & 18 \\
PR\&Advertising & 31.7 & 59 \\
Journalism & 17.2 & 32 \\
\hline
\end{tabular}

ANY KIND OF TRAINING BEFORE UNIVERSITY

\begin{tabular}{lccc}
\hline \hline yes & 7.5 & 14 \\
no & 92.5 & 172
\end{tabular}




\section{MEMBERSHIP TO ENVIRONMENTAL ASSOCIATIONS}

\begin{tabular}{llcc}
\hline \hline & yes & 15 & 28 \\
& no & 85 & 158 \\
$\mathrm{n}=186$ & & &
\end{tabular}

The findings presented in Table 1 shows that 111 people equal to $\% 60$ of the total respondents are male. Most of the students participated to this study are coming from Northwest Anatolia (36.6\%) and West Anatolia (20.4\%) and Central Anatolia (23\%). Education levels of the parents of respondents are too low. Most of the fathers $(42.2 \%)$ and mothers (63.2\%) graduated from compulsory level (the first 8 year in school, elementary and middle school) of education. In terms of the findings, the departments of Communication (41.4\%); Public Relations and Advertising (31.7\%) are represented too much, compare to other departments of the Communication Sciences Faculty. Most of the respondents $(92.5 \%)$ have no experience concerning the any kind of training before university. Additionally, most of the students (85\%) appear not to member of any kind of environmental associations.

The survey used in this study was translated into Turkish. Turkish version of the environmental consciousness survey was checked by the 2 experts of Turkish and English Languages. The Turkish version of the survey was retranslated into English and compared to original version.

The procedure about environmental consciousness scale was performed gradually. After assessing the overall reliabilities, principal components factor analysis was performed to ascertain the dimensionality of the scale. Then reliabilities were assessed for their subdimensions. The variables of concerning the gender, the region that they came from, their department in the faculty of communication sciences, education level of parents, any kind of training related to environmental issues or membership to any environmental associations finally assessed due to relationship between factors related to environmentally consciousness.

\section{Reliability and Factor Analysis}

In the scale of the study, items about environmentally responsible consumer behaviors, Haytko \& Matulich, (2008) used almost all the themes studied in their previous research. In 
their previous research environmental themes were widely borrowed from Ecological Attitudes and Knowledge Scale (EAKS). However, they did not include the item in their previous research was like that: "I am willing to give up driving on a weekend due to an ozone/smog alert." Also they added 17 more items like that: Some of the new items were about recycling (Laroche, Bergeron, Barbaro-Forleo, 2001; Brown and Wahlers, 1998), renewable energy (Rowlands, Scott and Parker, 2002), eco-labeling (Brown and Wahlers, 1998; Mohr, Eroglu, Ellen, 1998), climate change (Rowlands, Scott and Parker, 2002) and ecofriendly cars (Buss, 2001).

The most significant measure of reliability is coefficient alpha. In exploratory analyses an acceptable level of coefficient alpha is .70. is suggested (Nunnally,1978). The overall Cronbach's alpha for the Environmentally Responsible Behaviors scale was .852 across 47 items. After analyzing the items added by Haytko \& Matulich (2008), it was seen that the statistical values of that items too low and they were affecting two different factors. Therefore, item-to-total correlation analysis indicates that if q1-2-4-6-15-25-28-29 were deleted, Cronbach's alpha would improve to over .892 . The items were deleted are listed below:

1. I believe recycling will reduce pollution (.177)

2. I would be willing to pay an environmental tax to help decrease environmental problems (.112).

4. I rarely ever worry about the effects of the environment on me and my family. $(.057)$

6. I would be more willing to recycle if there were a monetary reward. (.190)

15. Recycling is important to save natural resources. (.198)

25. Even if everyone tried to conserve energy at home, it wouldn't make a big impact on energy use. (.128)

28. Recycling is too much trouble for me. (.157)

29. Most of the environmentally safe products I use are too hard to find. (-.074)

In the light of above mentioned results and deleted items, the factors presented in the study of Haytko \& Matulich (2008) were changed. The items (q.6,25,28,29) lowering the reliability were located in the factor of "Environmental Responsibility and Impact", This factor after deleting the items, it was eliminated because it has only 2 items left. 
In the survey of environmental consciousness, exploratory factor analysis was used. Table 2 shows the items and their loadings on each of the three factors. The first factor seems to describe awareness and act responses and the second factor is related to consumers' concerns about environment. Finally the third factor appears to describe consumers' willingness to specific behaviors regarding to environment.

Table 2

Thoughts and Behaviors about the Environment $(\mathrm{n}=186)$

\begin{tabular}{|c|c|c|c|}
\hline & M & SD & $\begin{array}{c}\text { Factor } \\
\text { Loadings }\end{array}$ \\
\hline \multicolumn{4}{|l|}{ Awareness and Act } \\
\hline 10. I am aware of recycling programs in the area. & 3.26 & 1.336 & 1 \\
\hline $\begin{array}{l}\text { 12. I understand the environmental phrases and symbols on } \\
\text { product packages. }\end{array}$ & 3.76 & 1.115 & 1 \\
\hline 11. I often subscribe to ecological publications. & 2.00 & 1.148 & 1 \\
\hline $\begin{array}{l}\text { 16. I often urge my friends to use products that are } \\
\text { advertised as being green. }\end{array}$ & 2.49 & 1.262 & 1 \\
\hline $\begin{array}{l}\text { 19. I refuse to buy products from companies accused of } \\
\text { being polluters. }\end{array}$ & 3.67 & 1.201 & 1 \\
\hline $\begin{array}{l}\text { 20. Keeping separate piles of garbage for recycling is too } \\
\text { much trouble me.* }\end{array}$ & 3.67 & 1.401 & 1 \\
\hline $\begin{array}{l}\text { 23. I often attend meetings of an organization specifically } \\
\text { concerned with bettering the environment. }\end{array}$ & 3.19 & 1.218 & 1 \\
\hline 24. I buy products in refillable containers. & 3.75 & 1.164 & 1 \\
\hline $\begin{array}{l}\text { 27. I make every attempt to join environmental cleanup } \\
\text { drives. }\end{array}$ & 3.19 & 1.173 & 1 \\
\hline $\begin{array}{l}\text { 31. I regularly keep track of my congressional } \\
\text { representatives' voting records on environmental issues. }\end{array}$ & 2.84 & 1.164 & 1 \\
\hline 32. I strive to conserve water in my home. & 4.24 & 1.030 & 1 \\
\hline
\end{tabular}




\begin{tabular}{|c|c|c|c|}
\hline 33. I read labels to see if contents are environmentally safe & 3.51 & 1.164 & 1 \\
\hline 38. I avoid buying products in aerosol containers. & 3.02 & 1.350 & 1 \\
\hline $\begin{array}{l}\text { 39. I regularly contact community agencies to find out what } \\
\text { I can do to help the environment. }\end{array}$ & 2.20 & 1.075 & 1 \\
\hline $\begin{array}{l}\text { 40. I've often bought products just because they were safer } \\
\text { for the environment. }\end{array}$ & 2.63 & 1.123 & 1 \\
\hline 42. I consider myself to be an environmentalist. & 3.17 & 3.17 & 1 \\
\hline $\begin{array}{l}\text { 44. I've changed my choice of many products for ecological } \\
\text { reasons. }\end{array}$ & 2.78 & 1.054 & 1 \\
\hline 45. I am a strong supporter of environmental regulation. & 3.38 & 1.129 & 1 \\
\hline $\begin{array}{l}\text { 46. I make a special effort to buy products with } \\
\text { environmentally friendly packaging. }\end{array}$ & 3.24 & 1.130 & 1 \\
\hline $\begin{array}{l}\text { 47. I try hard to use less heat in the winter and use less air } \\
\text { conditioning in the summer to conserve energy. }\end{array}$ & 3.37 & 1.280 & 1 \\
\hline Concern About Environment & & & \\
\hline $\begin{array}{l}\text { 3. I become upset when I think about the harm being done } \\
\text { to the environment. }\end{array}$ & 4.42 & .985 & 2 \\
\hline $\begin{array}{l}\text { 5. It is the government's job to help the environment, not } \\
\text { mine.* }\end{array}$ & 2,12 & 1,122 & \\
\hline $\begin{array}{l}\text { 9. When I think of the ways industries are destroying the } \\
\text { environment, I get frustrated. }\end{array}$ & 3.81 & 1.156 & 2 \\
\hline $\begin{array}{l}\text { 14. I feel people worry too much about environmental } \\
\text { contaminants in food products. }\end{array}$ & 2.88 & 1.233 & 2 \\
\hline $\begin{array}{l}\text { 18. I am very concerned about how climate change will } \\
\text { effect future generations. }\end{array}$ & 4.05 & 1.147 & 2 \\
\hline $\begin{array}{l}\text { 26. It frightens me to think that much of the food I eat may } \\
\text { be dangerous because of environmental contamination. }\end{array}$ & 3.98 & 1.136 & 2 \\
\hline $\begin{array}{l}\text { 34. The seriousness of environmental problems is } \\
\text { exaggerated by environmentalists.* }\end{array}$ & 1.96 & 1.131 & 2 \\
\hline
\end{tabular}




\begin{tabular}{|c|c|c|c|}
\hline $\begin{array}{l}\text { 36. It makes me angry to think that the government doesn't } \\
\text { do more to help control environmental problems. }\end{array}$ & 4.11 & 1.143 & 2 \\
\hline \multicolumn{4}{|l|}{ Willingness } \\
\hline $\begin{array}{l}\text { 7. I'd be willing to ride a bicycle or use public transportation } \\
\text { to go to work/school to reduce air pollution. }\end{array}$ & 3.89 & 1.247 & 3 \\
\hline $\begin{array}{l}\text { 8. I would purchase an environmentally-friendly car in my } \\
\text { budget even if it would be difficult to service. }\end{array}$ & 3.49 & 1.283 & 3 \\
\hline $\begin{array}{l}\text { 13. I'd be willing to write my congressional representative } \\
\text { concerning ecological problems. }\end{array}$ & 2.72 & 1.255 & 3 \\
\hline $\begin{array}{l}\text { 17. I would be willing to stop buying products from } \\
\text { companies guilty of harming the environment, even though } \\
\text { it might be inconvenient. }\end{array}$ & 3.27 & 1.276 & 3 \\
\hline $\begin{array}{l}\text { 21. I probably would go to a house to distribute literature on } \\
\text { the environment. }\end{array}$ & 2.70 & 1.338 & 3 \\
\hline $\begin{array}{l}\text { 22. I would be willing to donate a day's worth of pay to a } \\
\text { foundation to help them improve the environment. }\end{array}$ & 3.68 & 1.287 & 3 \\
\hline $\begin{array}{l}\text { 35. I would be willing to join a group or club which is } \\
\text { concerned solely with ecological issues. }\end{array}$ & 2.72 & 1.255 & 3 \\
\hline $\begin{array}{l}\text { 37. I strive to learn as much as possible about environmental } \\
\text { issues. }\end{array}$ & 3.65 & 1.056 & 3 \\
\hline $\begin{array}{l}\text { 41. I would pay extra on my electricity bill each month to } \\
\text { ensure that all of the electricity I use comes from 'green' } \\
\text { sources }\end{array}$ & 3.00 & 1.307 & 3 \\
\hline 43. I do my best to keep up-to-date on environmental issues. & 3.27 & 1.088 & 3 \\
\hline $\begin{array}{l}\text { 30. I feel that I am very knowledgeable about environmental } \\
\text { issues. }\end{array}$ & 2.81 & .948 & 3 \\
\hline
\end{tabular}

In the table 2, the means of "I become upset when I think about the harm being done to the environment" ( $m=4.42)$, "It makes me angry to think that the government doesn't do more to help control environmental problems" $(\mathrm{m}=4.11)$ in the factor of concern about environment; 
"I strive to conserve water in my home" $(\mathrm{m}=4.24)$ in the factor of awareness and act and looks higher than the other items. In the factor of willingness highest mean is 3.89 and it belongs to item "I'd be willing to ride a bicycle or use public transportation to go to work/school to reduce air pollution".

In addition to assessing the mean scores, standard deviations, t-values and F-values were calculated to examine potential differences in attitudes relating to environmental consciousness under the factors of awareness and act, concern about environment and willingness in terms of gender, the region that they came from, their department in the faculty of communication sciences, education level of parents, any kind of training related to environmental issues or membership to any environmental associations.

Table 3

Mean scores, Standard Deviations, and T-test for Respondent Attitude

Scores by Gender on Environmental Consciousness

\begin{tabular}{lccccc}
\hline Gender & Count & $\begin{array}{c}\text { Mean } \\
\text { score }\end{array}$ & $\begin{array}{c}\text { Standard } \\
\text { Deviation }\end{array}$ & $\begin{array}{c}\text { t-Value } \\
\text { Sign. Level } \\
(\alpha)\end{array}$ \\
\hline Male & 111 & 3.18 & .49 & -1.64 & .687 \\
Female & 75 & 3.30 & .51 & & \\
& & & & \\
\hline $\mathrm{n}=186$ & & & &
\end{tabular}

$\mathrm{n}=186$

The analysis in the Table 3 indicates that there was no significant difference in environmental consciousness due to gender, as the t-value was -1.64 . The Table 13 shows that the level of significance was $\alpha=.687$, which was clearly not statistically significant at the level of $\alpha \leq$ 0.05 , that is, male and female consumers were likely to show similar attitudes regarding their environmental consciousness. There is no significant difference in consumers' environmental consciousness due to gender $(\alpha \leq 0.05)$.

In Table 4, to assess if there was significant difference in consumers' environmental consciousness due to any kind of environmental training received before university $(\alpha \leq 0.05)$, 
mean scores, standard deviations and t-values were calculated. The results reveals that there was statistically significant difference between the people received any kind of training before university and others as the t-value was 2.370 .

\section{Table 4}

Mean scores, Standard Deviations, and T-test for Respondent Attitude

Scores by Any Kind of Training Received Before University on Environmental Consciousness

\begin{tabular}{lccccc}
\hline Env. Training & Count & $\begin{array}{c}\text { Mean } \\
\text { score }\end{array}$ & $\begin{array}{c}\text { Standard } \\
\text { Deviation }\end{array}$ & $\begin{array}{c}\text { t-Value } \\
\text { Sign. Level } \\
(\alpha)\end{array}$ \\
\hline Yes & 14 & 3.53 & .46 & 2.370 & .975 \\
No & 172 & 3.21 & .50 & & \\
& & & & \\
$\mathrm{n}=186$ & & &
\end{tabular}

Table 5

Mean scores, Standard Deviations, and T-test for Respondent Attitude

Scores by Membership to Environmental Associations on Environmental Consciousness

\begin{tabular}{lccccc} 
Membership & Count & $\begin{array}{c}\text { Mean } \\
\text { score }\end{array}$ & $\begin{array}{c}\text { Standard } \\
\text { Deviation }\end{array}$ & $\begin{array}{c}\text { Sign. Level } \\
(\alpha)\end{array}$ \\
\hline Yes & 28 & 3.45 & .50 & 2.622 & .473 \\
No & 158 & 3.19 & .49 & \\
& & & & \\
\hline $\mathrm{n}=186$ & & &
\end{tabular}

The analysis in the Table 5 shows that there was statistically significant difference in consumers' environmental consciousness due to membership to any kind of environmental associations, as the t-value was 2.622. In terms of the results were shown in Table 5, people 
have any kind of membership and the others were not likely to show similar attitudes regarding the environmental consciousness.

\section{Table 6}

Mean scores, Standard Deviations, and F-test for Respondent Attitude

Scores by Region They Coming From on Environmental Consciousness

\begin{tabular}{lccccc} 
Region & Count & $\begin{array}{c}\text { Mean } \\
\text { score }\end{array}$ & $\begin{array}{c}\text { Standard } \\
\text { Deviation }\end{array}$ & F-Value & $\begin{array}{c}\text { Sign. Level } \\
(\alpha)\end{array}$ \\
\hline Northwest & 68 & 3.27 & .50 & .650 & .584 \\
West & 38 & 3.13 & .54 & & \\
Central & 43 & 3.23 & .51 & \\
Other & 37 & 3.26 & .45 &
\end{tabular}

$\mathrm{n}=186$

The mean scores, standard deviations, and F-values were used to assess differences in students' attitudes related to environmental consciousness as the F-value was .584. From that perspective, the figures in Table 6 reveal that there is no significant difference in respondents' environmental consciousness in terms of the region of Anatolia that they came from $(\alpha \leq 0.05)$.

So as to examine if there was any statistically significant difference in terms of the educational level of the parents, mean scores, standard deviations, and F-values were used to assess differences in students' attitudes related to environmental consciousness as shown in Table 7. The research findings presented in the table 7 represents that there were no significant differences in students' attitudes concerning the environmental consciousness due to level of education of the parents. As indicated in the table, for the educational situation for the fathers, the level of significance was $\alpha=.877$, for the educational level of mothers was $\alpha$ $=.688$ which was not statistically significant at the level of $\alpha \leq 0.05$. 


\section{Table 7}

Mean scores, Standard Deviations, and F-test for Respondent Attitude

Scores by Educational Level of Father and Mother on Environmental Consciousness

\begin{tabular}{lccccc}
\hline $\begin{array}{l}\text { Education } \\
\text { (Father) }\end{array}$ & Count & $\begin{array}{c}\text { Mean } \\
\text { score }\end{array}$ & $\begin{array}{c}\text { Standard } \\
\text { Deviation }\end{array}$ & F-Value & $\begin{array}{c}\text { Sign. Level } \\
(\alpha)\end{array}$ \\
\hline & & & & .132 & .877 \\
Compulsory & 78 & 3.24 & .51 & & \\
High School & 63 & 3.21 & .45 & \\
University & 44 & 3.26 & .56 & \\
\end{tabular}

\section{Education}

(Mother)

\begin{tabular}{llllll}
\hline & & & & & \\
Compulsory & 78 & 3.22 & .48 & .688 \\
High School & 63 & 3.28 & .50 & \\
University & 44 & 3.17 & .62 &
\end{tabular}

$\mathrm{n}=186$

The figures in the Table 8 reveal that there is no significant difference in students' attitudes due to their departments, as the F-value was .195. The analysis indicates that the level of significance was $\alpha=.313$ which was not statistically significant at the level of $\alpha \leq 0.05$, that is, all the students of four departments are likely to be consistent in their attitudes regarding to environmental consciousness.

\section{Table 8}

Mean scores, Standard Deviations, and F-test for Respondent Attitude Scores by Their Departments on Environmental Consciousness

\begin{tabular}{|c|c|c|c|c|c|}
\hline Department & Count & $\begin{array}{l}\text { Mean } \\
\text { score }\end{array}$ & $\begin{array}{l}\text { Standard } \\
\text { Deviation }\end{array}$ & F-Value & $\begin{array}{c}\text { Sign. Level } \\
(\alpha)\end{array}$ \\
\hline
\end{tabular}




$\begin{array}{lllll}\text { Communication } & 77 & 3.22 & .48 & .195 \\ \text { Cinema and TV } & 18 & 3.31 & .42 & .313 \\ \text { PR and Ad } & 59 & 3.15 & .54 & .51 \\ \text { Journalism } & 32 & 3.35 & & \\ & & & \end{array}$

$\mathrm{n}=186$

\section{Conclusion}

The study concludes that, there were not significant differences in the attitudes of respondents in terms of their gender, the region that they came from, their department in the faculty of communication sciences, education level of parents. The respondents have familiar attitudes towards to environmental consciousness from the perspective of the factors related to awareness and act, concern about environment and willingness. However, the attitudes of the respondents due to any kind of training received concerning the environmental issues before entering university and any environmental associations or social club memberships were statistically significant. The attitudes of students received any kind of training concerning the environment or any kinds of membership to environmental associations were differed from the others. For that reason, several compulsory or selective courses will take place in the instruction of the high schools even in the first eight years of the education in Turkey, to increase awareness regarding to environmental issues. In the light of data gathered from this study, new obligatory or selective courses about environmental issues will be added to instruction of Communication Faculty, because the graduates of this faculty, besides being a consumer, they will be the communication professionals responsible from organization of the communication activities regarding to environmental issues. They will design social campaigns and make advertisements, cinema and TV films. Additionally, the number of the environmental associations should be increased and the students should be stimulated to participate to activities of these associations. Also based on the data taken from this study will be used to design further studies concerning the social campaigns about environmental consciousness and green consumerism. 


\section{References}

Alsmadi, S. (2007). 'Green Marketing and the Concern over the Environment:

Measuring Environmental Consciousness of Jordanian Consumers', Journal of Promotion Management, 13:3,339 - 361

Brown, J. D., and Wahlers, R., G. (1998), “The Environmentally Concerned Consumer: An Explanatory Study," Journal of Marketing Theory and Practice, 6 (2), 39-48.

Buss, D. (2001), “Green Cars,” American Demographics, 23 (1), 56-62.

Haytko,D.,L \& Matulich, E (2008). Green Advertising and Environmentally Responsible Consumer Behaviors: Linkages Examined Journal of Management and Marketing Research, Volume 1, Page 2

Doğan, M. (2003). Sanayileşme ve Çevre Sorunları (http://yunus.hacettepe.edu.tr/ dogan/4.html et:05.11.2006)

Laroche, M., Bergeron, J., and Barbaro-Forleo. (2001). Targeting consumers who are willing to pay more for environmentally friendly products. Journal of Consumer Marketing, $18(6), 503-520$.

Major,A., M.(1993). Environmental Concern and Situational Communication Theory: Implications for Communicating With Environmental Publics. Journal of Public Relations Research, 5(4), 251-268

Miran, B., Günden, C. and Sahin, A. (2008). Awareness to Environmental Pollution. Presented at Southern Agricultural Economics Association Annual Meeting, Dallas Mohr, L., A., Eroglu, D. and Ellen, P.S. (1998), “The Development and Testing of a Measure of Skepticism Toward Environmental Claims in Marketers' Communications," The Journal of Consumer Affairs, 32 (1), 30.

Mostafa, M.,M. (2007). A Hierarchical Analysis of the Green Consciousness of the Egyptian Consumer. Psychology \& Marketing, Vol. 24(5): 445-473.

Nunnally, J., C. (1978), Psychometric Theory, Second Edition, New York: McGraw Hill Book Company

Rowlands, I., H., Parker, P., Scott, D. (2002), “Consumer Perceptions of Green Power,” The Journal of Consumer Marketing, 19 (2/3), 112-130.

Schoenfeld, C. and Ross, J., E. (1978). A 'new profession' Environmental communication programs 'come of age'. Journalism Educator, v33 n2 p3-6,61-64 Jul 1978. 
Yücel, M, Altunkasa F, Güçray S, Uslu C, Say N., P. (2006) Adana' da çevre duyarlılı̆̆ı düzeyinin ve geliştirme olanaklarının araştırılması, Akdeniz Üniversitesi Ziraat Fakültesi Dergisi, 19(2), 217-228.

(http://www.nuce.boun.edu.tr/turkey.html). 11.10.2009 